\title{
Nečinnost a nezákonný zásah ve veřejné správě - rozdílné kategorie, či nikoliv?
}

\author{
Inactivity and Unlawful Interference in Public \\ Administration - Different Categories or not?
}

František Halml*

\begin{abstract}
Abstrakt
Podstatu verejné správy predstavije správa jako aktivni konáni správnich orgámi. Opakem činnosti veréejné správy je nečinnost, keterá je nežăádoucím jevem ve verejné správě. Dalš kategorii nežádoucíbo jednání veréjné správy predstaviji nezákonné zásaby. Ochranu subjektivnich práv verejné povaby ve zkoumané oblasti poskytuje žaloba proti nečinnosti a zásahová žaloba. Nečinnost a nezákonný zásah ve verejné správě vykazuji mnoho společných znakư, což potvrdila rejména judikatura Nejyyššího správního soudu. Objevuji se názory o vhodnosti sloučeni uvedených žalobnich typi s tím, že by nadále byla jakákoliv nečinnost pokládána za nezákonný zásah. Cílem článku je zhodnoceni odivodnènosti samostatné existence uvedených žalobnich typu kvili jejich velmi podobným rysim.
\end{abstract}

\section{Klíčová slova}

Nečinnost; nezákonný zásab; žaloba proti nečinnosti; žaloba na ochranu pred nezákonným zásahem.

\begin{abstract}
Substance of public administration represents administration as active actions of administrative bodies. The opposite of public administration activity is an inactivity, which is undesirable phenomenon in public administration. Another category of undesirable activity represents unlawful interference. Protection of public subjective rights in the area of interest is provided by action against inactivity and action against unlawful interference. Inactivity and unlawful interference in public administration have many common features, which was confirmed especially by judgements of Supreme Administrative Court. In theory keep appearing opinions about suitability of connection of stated action's type with idea that any kind of inactivity in public administration would be regarded as unawful interference. The main objective set out in this article is to evaluate legitimacy of separate existence of the stated action types, mainly because their features are very similar.
\end{abstract}

\section{Keywords}

Inactivity; Unlawful Interference; Action Against Inactivity; Action Against Unlawful Interference.

\section{Úvod}

Nečinnost a nezákonný zásah ve veřejné správě představují nežádoucí formy realizace veřejné správy. Veřejná správa umožňuje domáhat se nápravy nečinnosti správního orgánu vždy, zatímco náprava nezákonného zásahu je možná v rámci veřejné správy

\footnotetext{
* Mgr. František Halml, doktorand, Katedra správní vědy a správního práva, Právnická fakulta, Masarykova univerzita, Brno / Ph.D. student, Department of Administrative Science and Administrative Law, Faculty of Law, Masaryk University, Brno, Czech Republic / E-mail: halml.f@seznam.cz
} 
spíše výjimečně. Správní soudnictví se k soudnímu přezkumu nečinnosti a nezákonných zásahů ve veřejné správě staví poněkud odlišně. Přitom nečinnost a nezákonný zásah ve veřejné správě si jsou v mnohých rysech podobny.

Tento článek si klade za cíl srovnat nečinnost a nezákonný zásah ve veřejné správě, nečinnostní a zásahovou žalobu zejména z hlediska jejich př́ipustnosti. Poslední kapitola článku je věnována srovnání uvedených žalobních typů z důvodu posouzení opodstatněnosti jejich samostatné existence, $\mathrm{kdy} v$ některých př́ípadech ochrany proti nečinnosti je namísto nečinnostní žaloby použitelná pouze zásahová žaloba. Zda je taková praxe správná, a jaká jsou možná řešení do budoucnosti, bude v článku uvedeno.

\section{Vymezení nečinnosti a nezákonného zásahu ve veřejné správě}

Veřejná správa představuje správu záležitostí ve veřejném zájmu. Aby byla schopna naplnit své poslání, musí být realizována podle určitých, předem stanovených pravidel. Uvedená pravidla jsou mimo jiné obsažena v základních zásadách činnosti správních orgánů. Pro téma tohoto př́spěvku představují nejdůležitější zásady tzv. zásada rychlosti vyjádřená v ustanovení \ 6 odst. 1 zákona č. 500/2004 Sb., správní rád, ve znění pozdějších předpisů (dále jen „SpŘ “) a tzv. zásada zákonnosti (legality), jež je vyjádřena v ustanovení $\int 2$ odst. 1 Spř. Nečinnost a nezákonné zásahy ve veřejné správě se dotýkají i dalších základních zásad, jež pro účely tohoto článku ponechávám stranou pozornosti.

Nečinností lze rozumět opak činnosti jako aktivního jednání veřejné správy spočívající ve správě záležitostí ve veřejném zájmu, tedy s cílem realizovat veřejnou správu některou z forem činnosti veřejné správy. Činnost vyjadřuje cílevědomé konání orgánů veřejné správy. Nečinnost naopak představuje pasivitu takového jednání v případech, kdy správní orgán nejedná, ačkoliv mu povinnost jednat zákon ukládá; 'jedná se o tzv. nezákonnou nečinnost coby negativní jev ve veřejné správě s důsledkem nesprávného výkonu veřejné správy a v rozporu s podstatou samotné veřejné správy. ${ }^{2}$ Výjimku z povinnosti jednat představuje např. správní uvážení, zda konat, či nikoliv ${ }^{3}$, v př́padech, kdy jednat nemusí. Definici nečinnosti pozitivní právo neobsahuje. Je to dáno díky tomu, že nečinnost ve veřejné správě představuje pojem zahrnující široké spektrum př́padů nekonání, který je třeba vykládat ad hoc, tedy vzhledem ke konkrétnímu případu. Nelze tak předem stanovit, kdy se o nečinnost jedná, jelikož nečinnost může nabývat různých podob (obdobně jako nezákonný zásah).

Proti nečinnosti upravuje správní řád tzv. prostředky proti nečinnosti. Umožňuje v případě nevydání meritorního rozhodnutí v zákonné lhůtě zásah nadřízeného správního orgánu

1 Rozsudek Nejvyššího správního soudu ze dne 15. 12. 2004, č. j. 2 Ans 4/2004-116, vyhlášený pod č. 506/2005 Sb. NSS.

2 SEDLÁČEK, S. Soudni kontrola verejné správy. 1. vyd. Brno: Masarykova univerzita, 2011, s. 55.

3 POTĚŠIL, L. a kol. Správní rád: komentár. 1. vyd. Praha: C. H. Beck, 2015, s. 379. 
$\mathrm{z}$ moci úřední ( $\mathrm{v}$ rámci tzv. instanční kontroly ${ }^{4}$, dozorové funkce ${ }^{5}$ ), a to i v př́padě, kdy lhưta pro vydání rozhodnutí dosud neuplynula, ale z okolností je zjevné, že věcně a místně prríslušný správní orgán nedodrží lhůtu stanovenou pro vydání rozhodnutí o žádosti nebo povinnost zahájit řízení z moci úřední anebo v rrízení řádně pokračovat, popř. na základě žádosti účastníka řízení. Ustanovení \ 80 SpŘ se užije na jakékoliv postupy a úkony správních orgánů, na něž se vztahuje správní řád. ${ }^{6}$ Je to dáno díky odkazu v ustanovení \6 odst. $1 \mathrm{SpR}$. O nečinnost se jedná i v případě, že správní orgán nezahájí ve lhưtě 30 dní ode dne, kdy se dozvěděl o skutečnostech odůvodňujících řízení z moci úřední. Účastník již zahájeného správního řízení může podat k nadřízenému správnímu orgánu žádost o uplatnění opatření proti nečinnosti. Opatření proti nečinnosti představují přikázání nečinnému správnímu orgánu konat (učinit potřebná opatření ke zjednání nápravy nebo vydat rozhodnutî), atrakci, delegaci a priměřené prodloužení zákonné lhůty pro vydání rozhodnutí (tzv. prolongace), lze-li důvodně předpokládat, že správní orgán v prodloužené lhưtě vydá rozhodnutí ve věci, a zároveň je takový postup pro účastníky výhodnější. Nejúčinnějším prostředkem bývá právě poslední možnost, tedy prolongace. Je to dáno skutečností, že správní orgán v daném řízení často již koná, avšak není schopen dostát zákonné lhưtě nebo lhůtě přiměřené, pokud jde o samotné vydání meritorního rozhodnutí. Prolongace je ovšem možná pouze za výše uvedených předpokladů. Pro účastníka řízení tak zpravidla bývá přijatelnější prodloužení lhůty např̀. o několik dnů, než přesunutí povinnosti rozhodnout na jiný správní orgán, což bývá zpravidla proces vedoucí k vydání rozhodnutí v delším časovém horizontu a zároveň dochází k „oddáleni““ účastníka řízení a př́islušného správního orgánu. Při volbě opatření proti nečinnosti se nadřízený správní orgán musí rídit zejména zásadou procesní ekonomie, tedy dostát apelu na minimalizaci nákladů a hospodárnost postupů s cílem efektivního výkonu veřejné správy. Přiměřené prodloužení lhůty pro vydání rozhodnutí neslouží k nápravě skutečnosti, kdy jedním z častých důvodů nečinnosti správního orgánu bývá nedostatečné personální obsazení úřadu ${ }^{7}$ a z toho plynoucí přetíženosti takového správního orgánu. Žádná příčina totiž nemůže ospravedlnit nezákonnou nečinnost. ${ }^{8}$ Posouzení vhodnosti opatření proti nečinnosti je tudíž ze strany nadřízeného správního orgánu zapotřebí posuzovat ad hoc podle jeho uvážení. Nelze předem stanovit postup nadřízeného správního orgánu ve volbě opatření proti nečinnosti.

4 HORZINKOVÁ, E. a Z. FIALA. Správni právo hmotné. Obecná část. 2. vyd. Praha: Leges, 2015, s. 138.

5 KLIKOVÁ, A. a kol. Spránní rád. 2. vyd. Praha: Wolters Kluwer ČR, 2016, s. 72; Stejně i SKULOVÁ, S. a kol. Prostredky ochrany subjektivnich práv ve verejné správě - jejich systém a efektivnost. 1. vyd. Praha: C. H. Beck, 2017, s. 22.

6 VEDRAL, J. Správní rád: komentár. 2. aktualizované a rozšířené vyd. Praha: Ivana Hexnerová - Bova Polygon, 2012, s. 691.

POTĚŠIL, L. a kol. Soudni rád správni: komentár. 1. vyd. Praha: Leges, 2014, s. 752.

7 HENDRYCH, D. a kol. Správní právo. Obecná ćást. 8. vyd. Praha: C. H. Beck, 2012, s. 718.

8 Nález Ústavního soudu ze dne 12.1. 1999, sp. zn. I. ÚS 209/98. Stejně tak i rozsudek Nejvyššího správního soudu ze dne 31. 5. 2018, č. j. 9 As 36/2018-37, kterým konstatoval, že přetíženost a omezené personální kapacity stěžovatele (úřadu) nemohou být účastníkům řízení na újmu. 
$\mathrm{V}$ rámci nečinnosti je možné rozlišovat 2 okruhy případů nečinnosti. ${ }^{9}$ Jedním okruhem jsou případy, kdy správní ř́zení již bylo zahájeno a k průtahům dochází v jeho průběhu, popř. situace, kdy správní orgán dosud správní řízení nezahájill, ač tak učinit měl. ${ }^{10}$ Druhý okruh představují situace, kdy k nečinnosti došlo v již skončeném řízení. ${ }^{11}$ Opatření proti nečinnosti lze uplatnit pouze proti nezahájení správního ř́zení, popř. nevydání správního rozhodnutí, nikoliv proti nečinnosti v již skončeném řízení.

Zásah ve veřejné správě v pozitivním slova smyslu (zákonný) představuje jednu z forem činnosti veřejné správy. Zásah společně s faktickými pokyny, exekučními úkony a zajišt’ovacími úkony představují kategorii tzv. faktických pokynů s bezprostředními právními důsledky. Často je ale kategorie faktických úkonů a (nezákonného) zásahu zaměňována, spíše je namísto pojmu faktické úkony používán pojem (nezákonný) zásah, což bezesporu souvisí s právní úpravou obsaženou v zákoně č. 150/2002 Sb. soudní řád správní, ve znění pozdějších předpisů (dále jen „SŘS“). Zásahy ovšem mohou být realizovány v rozporu se zásadou zákonnosti veřejné správy; jedná se o kategorii tzv. nezákonných zásahů ve veřejné správě. Zásah (obecně však jakýkoliv faktický úkon) teorie správního práva vymezuje jako úkon správního orgánu, který není činěn formou rozhodnutí (formalizovaným způsobem), směřuje vůči adresátům, pro které je závazný a ty jsou povinny na jeho základě něco konat, nějaké činnosti se zdržet nebo nějaké jednání strpět. Nezákonný zásah je možné stanovit jako úkon správního orgánu s výše uvedenými znaky, který byl proveden v rozporu se zásadou zákonnosti. Definici zásahu stejně jako nečinnosti platná právní úprava neobsahuje. ${ }^{12}$ Důvod je vcelku prostý - výčet zásahů není taxativní, kdy není v silách zákonodárce pamatovat na všechny možné případy zásahu, a navíc jsou zásahy často obsaženy ve zvláštních předpisech a vyznačují se některými specifiky. S pojmem nezákonný zásah se lze setkat pouze v soudním řádu správním. Správní řád nezákonný zásah neupravuje, neposkytuje proti němu ani žádný obecný prostředek nápravy. ${ }^{13}$ Soudní řád správní v ustanovení \ 82 o zásahu uvádí, že „každý, kdo tvrdí, že byl primo zkerácen na svých právech nezákonným zásahem, pokynem nebo donucením (dále jen ,zásab") správního orgánu... ", čímž předvídá, že zásah má dvojí smysl - užší a širší. Nezákonný zásah largo sensu představuje legislativní zkratku pro 3 druhy „zásahư“, kterými jsou nezákonný zásah stricto sensu, nezákonný pokyn a nezákonné donucení. Jelikož legální definice

9 POTĚŠIL, L. a kol., 2015, op. cit., s. 380.

10 KLIKOVÁ, A. a kol., 2016, op. cit., s. 71.

11 POTĚŠIL, L. a kol., 2014, op. cit., s. 754.

12 Rozsudek Nejvyššího správního soudu ze dne 1. 12. 2004, č. j. 3 As 52/2003-278.

13 PRŮCHA, P. Podstata a funkce správního soudnictví ve vztahu k ochraně veřejných subjektivních práv. In: SKULOVÁ, S. a kol. Prostredky ochrany subjektivních práv ve verejné správě. 1. vyd. Brno: Masarykova univerzita, 2014, s. 140. Jako specifické prostředky proti nezákonným zásahům ve veřejné správě lze jmenovat námitky proti exekučním úkonům dle $\int 117 \mathrm{SpŘn}$, podnět $\mathrm{k}$ zahájení přezkumného ř́zení dle $\int 94$ odst. $1 \mathrm{SpR}$, neformálním prostředkem je stížnost podle $\int 175$ SpŘ. Další opravné prostředky jsou obsaženy např̀. v zákoně č. 273/2008 Sb., o Policii České republiky, ve znění pozdějších předpisů ve vztahu k úkonům Policie ČR. 
(nezákonného) zásahu neexistuje (a, jak již bylo uvedeno, ani díky rozmanitým prípadům zásahů existovat vlastně nemůže), musela se výkladu chopit judikatura. Nezákonný zásah počáteční judikatura Nejvyššího správního soudu vymezovala jako „,.. jednorázový a protiprávni útok orgánư verejné moci viuci základnim ústavně zaručeným práviom, který v dobè svébo puisobeni predstavuje trvalé obroženi stavu po právu existujicího. "14 Nezákonný zásah se postupem doby stal širším pojmem, kdy nezákonný zásah může být jednorázový, a to bud’ s trvajícími, nebo již ukončenými následky, dále i trvající nebo opakující se. Navíc zásahem není pouhý zásah do základních ústavně garantovaných práv, ale nezákonným zásahem může být i zásah do práv zaručených zákonem. Nezákonný zásah může spočívat i v pasivitě (nečinnosti) správního orgánu, nikoli pouze $\mathrm{v}$ aktivním konání. O této problematice bude v př́spěvku pojednáno.

\section{Nečinnost a nezákonný zásah ve správním soudnictví}

Správní soudnictví je založeno na tzv. zásadě subsidiarity, ${ }^{15}$ tzn., že ve správním soudnictví se lze domáhat ochrany práv jen na návrh a po vyčerpání řádných opravných prostředků, připouští-li je zvláštní zákon. $V$ př́padě nezákonného zásahu, jak již bylo uvedeno, obecný opravný prostředek veřejná správa neposkytuje (pominu-li opravné prostředky v rámci zvláštních zákonů). Žalobce se zpravidla může ihned domáhat ochrany svých veřejných subjektivních práv žalobou proti nezákonnému zásahu, pokynu nebo donucení správního orgánu (zásahovou žalobou). Pokud se jedná o žalobu proti nečinnosti správního orgánu (nečinnostní žalobu), před jejím podáním musí být účastníkem řízení nejčastěji vyčerpána žádost $\mathrm{k}$ nadřízenému správnímu orgánu o uplatnění opatření proti nečinnosti dle ustanovení $\int 80$ odst. 3 SpŘ.${ }^{16}$ Vyčerpání prostředku nápravy ve veřejné správě před podáním žaloby představuje podmínku přípustnosti uvedených žalobních typů.

Žaloba proti nečinnosti umožňuje účastníkovi správního řízení domoci se ochrany veřejných subjektivních práv proti nečinnosti správního orgánu. První odstavec ustanovení \79 SŘS upravuje již zmíněnou subsidiaritu nečinnostní žaloby, kdy ochrany proti nečinnosti se lze domáhat po bezvýsledném vyčerpání prostředků nápravy (pokud takové prostředky nápravy a ochrany na úrovni veřejné správy a správních orgánů existuji $1^{17}$

14 Rozsudek Nejvyššího správního soudu ze dne 1. 12. 2004, č. j. 3 As 52/2003-278.

15 Ustanovení 5 SŘS.

16 Rozsudek Nejvyššího správního soudu ze dne 26. 2. 2004, č. j. 1 Ans 1/2003-50. Do doby nabytí účinnosti současného správního řádu (tedy v době od 1. 1. 2003 do 31. 12. 2005) bylo možné se na správní soud obrátit ihned, jelikož dřivější správní rád opatření proti nečinnosti neobsahoval. $\mathrm{K}$ tomu srov. např. rozsudek Nejvyššího správního soudu ze dne 25. 11. 2003, č. j. 5 As 21/2003-40.

17 POTĚŠIL, L. a kol., 2014, op. cit., s. 754. K tomu srov. rozsudek Nejvyššího správního soudu ze dne 25. 11. 2003, č. j. 5 As 21/2003-40, publikovaný pod č. 491/2003 Sb. NSS, který stanovil, že pokud procesní předpis takový prostředek neobsahuje, nelze požadovat, aby žalobce vyhledával alternativní prostředky, jimiž by tuto podmínku splnil. 
a je jimi možné dosáhnout nápravy nečinnosti ${ }^{18}$ ), které stanoví procesní předpis platný pro řízení u správního orgánu k ochraně proti nečinnosti. Obecným prostředkem proti nečinnosti $\mathrm{v}$ rámci veřejné správy je žádost o uplatnění opatření proti nečinnosti dle ustanovení \ 80 odst. 3 SpŘ ${ }^{19}$ s tím, že zvláštní zákony mohou upravovat jiné prostředky nápravy. Podmínka bezvýsledného vyčerpání prostředků nápravy odpadá v př́padech, kdy procesní předpis platný pro rrízení u správního orgánu žádný prostředek proti nečinnosti nestanoví20 a žalobu proti nečinnosti lze podat ihned.

Žádost o uplatnění opatření proti nečinnosti se uplatňuje, jak již bylo v předchozí kapitole uvedeno, u nadřizeného správního orgánu, a to po uplynutí lhưt pro vydání rozhodnutí. Tuto běžnou praxi v souladu se zákonem narušil rozsudek Městského soudu v Praze, ${ }^{21}$ kdy rozhodl, že za řádné vyčerpání prostředku proti nečinnosti správního orgánu považuje

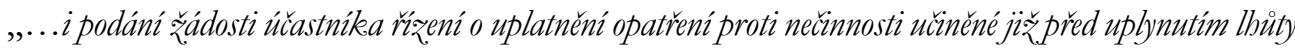
pro vydáni rozhodnutí ve smyslu $\int 80$ odst. 3 véta druhá SpŘ pokud je již ke dni podáni této žádosti z. konkrétnich okolnosti prǒpadu zjevné, že správni orgán je a bude nečinny". Osobně se tímto rozhodnutím neztotožňuji a považuji ho za překročení rozhodovací pravomoci, jelikož soud má povinnost aplikovat právo de lege lata (platné právo), nikoliv právo de lege ferenda. Samotný správní řád takové řešení nepřipouští. Ačkoliv je před samotným uplynutím lhůty pro vydání rozhodnutí ve smyslu \80 odst. 3 SpŘ zřejmé, že správní orgán je a bude nečinný, nelze přehlížet zákonnou úpravu. Uvedený úkon může učinit pouze nadřízený správní orgán, nikoliv účastník řízení; ten musí vyčkat uplynutí lhůt pro vydání rozhodnutí. Městský soud se částečně odklonil od názoru vysloveného Nejvyšším správním soudem, a to z hlediska podmínky vyčerpání opatření proti nečinnosti. Ačkoliv se rozhodnutí Nejvyššího správního soudu sp. zn. 9 Ans 8/2009 zabývá podmínkami př́pustnosti nečinnostní žaloby a nikoliv včasností žádosti o uplatnění prostředku proti nečinnosti, má uvedený rozsudek Městského soudu v Praze přesah i do roviny přípustnosti nečinnostní žaloby. Správnost postupu správních orgánů při vyřizování nečinnosti v rámci veřejné správy je základem pro úspěšné obhájení takového postupu v rámci soudního přezkumu nečinnosti.

Pokud je instančně nadřízený správní orgán, jenž má vykonávat instanční kontrolu dle ustanovení $\int 80$ SpŘ, nečinný, a je mu nadřízen další správní orgán, lze se ochrany proti nečinnosti domáhat právě u něj. ${ }^{22}$ Teprve tak je žaloba proti nečinnosti prrípustná.

18 Rozsudek Nejvyššího správního soudu ze dne 25. 7. 2007, č. j. 2 Ans 4/2007-53, publikovaný pod č. 1348/2007 Sb. NSS.

19 JEMELKA, L. a kol. Správní rád. Komentár. 5. vyd. Praha: C. H. Beck, 2016, s. 453.

KLIKOVÁ, A. a kol., 2016, op. cit., s. 71.

Rozsudek Nejvyššího správního soudu ze dne 18. 12. 2012, č. j. 9 Ans 16/2012-84.

Usnesení Krajského soudu v Plzni ze dne 20. 10. 2006, č. j. 57 Ca 61/2006-54.

20 JEMELKA, L. a kol., 2013, op. cit., s. 668.

21 Rozsudek Městského soudu v Praze ze dne 19. 12. 2016, č. j. 9 A 132/2016-69.

22 VEDRAL, J., 2012, op. cit., s. 692. P. Kolman zastává opačný názor. K tomu srov. FRUMAROVÁ, K. Ochrana prè nečinnosti verejné správy. Praha: Leges, 2012, s. 80. 
Žalobce musí vyčerpat žádost o uplatnění opatření proti nečinnosti rovněž v případech, kdy se domáhá ochrany proti nečinnosti ústředního orgánu státní správy (ústředního správního úřadu). ${ }^{23} \mathrm{~S}$ tímto názorem však J. Vedral ${ }^{24}$ nesouhlasí a zastává názor, že není nutné vyčerpávat žádost o uplatněné opatření proti nečinnosti dle ustanovení $\int 80$ SpŘ ve vztahu k ústřednímu správnímu úřadu. Uvedený názor J. Vedrala nezastávám. Osobně se přikláním k názoru vyslovenému v disentech soudců P. Průchy a J. Vlašína, podle kterého by se mělo rozlišovat dvojjediné postavení ústředních orgánů státní správy, kdy v jediné roli vystupuje současně jako správní orgán rozhodující v prvním stupni a současně v postavení nadřízeného správního orgánu. Povinnost vyčerpat žádost o uplatnění opatření proti nečinnosti by se dle disentů měla uplatnit pouze $\mathrm{v}$ př́padě rozhodování ústředního orgánu státní správy v prvním stupni. Rozhodnutí rozšířeného senátu Nejvyššího správního soudu považuji za ne zcela domyšlené do důsledku. Jelikož ústřední orgán státní správy již žádný instančně nadřízený správní orgán nemá, pokládám si otázku, jak by měl nečinný ústřední správní úrad postupovat $\mathrm{v}$ situaci, kdy zaujímá postavení nadřízeného správního orgánu? Požadavek v podobě vyčerpání prostředku k ochraně proti nečinnosti před podáním nečinnostní žaloby se tak uplatnit nemůže z důvodu právní i faktické neexistence správního orgánu, jak ostatně vyplývá z disentů. Důsledkem uvedeného rozhodnutí je tedy požadavek postupovat dle ustanovení $\int 80$ odst. 3 SpŘ i v př́padech, kdy žádný nadřízený správní orgán neexistuje. Závěrem k rozhodnutí uvádím, že si rozšířený senát neuvědomil dosah svého rozhodnutí a omezil se pouze na konkrétní případ. V budoucnosti lze očekávat, že vyslovený názor rozšířeného senátu bude překonán.

Pravidlo o prrípustnosti žaloby proti nečinnosti vyžaduje již zahájené správní řízení; nelze se domáhat nápravy nečinnosti správního orgánu ve správním soudnictví před zahájením správního řízení. ${ }^{25}$ Bezvýsledné vyčerpání prostředků nápravy ve veřejné správě coby podmínka př́pustnosti žaloby proti nečinnosti může mít 2 podoby, ${ }^{26}$ a to:

a) nadřízený správní orgán žádosti o uplatnění opatření proti nečinnosti podané účastníkem řízení dle ustanovení $\int 80$ odst. 6 nevyhovi ${ }^{27}$ (žádost usnesením zamítne) popř.

23 Usnesení rozšířeného senátu Nejvyššího správního soudu ze dne 20. 5. 2014, č. j. 8 Ans 2/2012-278, publikované pod číslem 3071/2014 Sb. NSS.

24 VEDRAL, J., 2012, op. cit., s. 693 a 702.

25 Rozsudek Nejvyššího správního soudu ze dne 15. 11. 2007, č. j. 6 Ans 2/2007-128, publikovaný pod č. $1486 / 2008$ Sb. NSS.

26 Usnesení Krajského soudu v Plzni ze dne 20. 10. 2006, č. j. 57 Ca 61/2006-54 a rozsudek Nejvyššího správního soudu ze dne 16. 9. 2009, č. j. 1 Ans 2/2009-79.

27 Usnesení Krajského soudu v Praze ze dne 26. 11. 2010, č. j. 44 A 61/2010-25. Jako důvod podání nečinnostní žaloby Krajský soud v Praze shledal i vydání rozhodnutí, které je nezpůsobilé zajistit ochranu účastníka řízení proti nečinnosti správního orgánu (např. neúměrně dlouhá lhůta ke zjednání nápravy v porovnání s oprávněnými zájmy účastníka řízení a složitostí potřebných opatření k nápravě nečinnosti). K nepřiměřené délce lhůty pro vydání rozhodnutí v důsledku jejího opakovaného prodlužování srov. rozsudek Nejvyššího správního soudu ze dne 6. 2. 2013, č. j. 1 Ans 19/2012-43, vyhlášený pod č. $2867 / 2013$ Sb. NSS. 
b) o žádosti ve lhůtě 30 dní nerozhodl ${ }^{28}$.

Bezvýsledným vyčerpáním prostředku nápravy nečinnosti je i případ, kdy správní orgán zůstane nečinný i po rozhodnutí o prostředku proti nečinnosti nadřízeným správním orgánem. ${ }^{29}$ Naopak bezvýsledným vyčerpáním prostředků nápravy nečinnosti není nevyhovění návrhu žalobce, kdy nadřízený správní orgán současně vybere jiný (vhodnějšîi) prostředek nápravy. ${ }^{30}$ Nadřízený správní orgán není návrhem účastníka správního řízení vázán, ${ }^{31}$ jelikož žádost o uplatnění opatření proti nečinnosti má formu spíše podnětu než žádosti o zahájení řízení. Přitom platí, že ,prĭjme-li nadř̌zený správni orgán opatření proti nečinnosti, je tím presumován faket, že správni orgán byl nečinný. "32

V záležitosti včasnosti podání nečinnostní žaloby judikatura zaznamenala určitý posun. Původně bylo judikováno, že žalobu může účastník řízení podat i v době, kdy dosud nebylo učiněno opatření proti nečinnosti, resp. neuplynula lhưta určená ke zjednání nápravy s tím, že (krajský, resp. Městský soud v Praze) má vyčkat, jakým způsobem se žádostí o uplatnění opatření proti nečinnosti nadřízený správní orgán naloží. ${ }^{33}$ Nejvyšší správní soud ${ }^{34}$ se však od výše uvedeného názoru odklonil a konstatoval, že žalobce musí bezvýsledně vyčerpat prostředky ochrany proti nečinnosti poskytované samotnou veřejnou správou již v době před podáním nečinnostní žaloby. Účastník řízení (žalobce) pro splnění podmínky bezvýsledného vyčerpání prostředků ochrany proti nečinnosti musí nejen podat žádost o uplatnění opatření proti nečinnosti dle ustanovení $\int 80$ odst. 3 $\mathrm{SpR}$, ale také „... musi vždy vyčkat výsledku učinèných opatreni proti neřinnosti, véetně stanovených lhưt pro jejich provedení, a tato opatreni nápravný úcinek neprinesou "35 Pokud by účastník ruizení nemusel vyčkat výsledku učiněných opatření proti nečinnosti, nečinnostní žaloba by byla př́pustná bez splnění výše uvedené podmínky, čímž by se takové ustanovení stalo nadbytečným. Veřejná správa $v$ případě ochrany proti nečinnosti by se dostala do totožného postavení, jako tomu je u nezákonného zásahu, kdy takový stav nepovažuji za zcela správný (o tom dále v textu př́spěvku). Předčasné podání žaloby proti nečinnosti tak představuje další případ bezvýsledného vyčerpání prostředků k ochraně proti nečinnosti, jehož následkem bude odmítnutí žaloby.

28 Rozsudek Nejvyššího správního soudu ze dne 15. 11. 2012, č. j. 2 Ans 13/2012-14 a mnohé další.

29 Rozsudek Nejvyššího správního soudu ze dne 18. 9. 2018, č. j. 6 As 219/2018-23.

30 Usnesení Krajského soudu v Ostravě ze dne 27. 1. 2010, č. j. 22 Ca 315/2009-23.

31 JEMELKA, L. a kol., 2016, op. cit., s. 454.

32 POTĚŠIL, L. a kol., 2015, op. cit., s. 383. K tomu srov. rozsudek Nejvyššího správního soudu ze dne 10. 12. 2012, č. j. 2 Ans 14/2012-41, publikovaný pod č. 2785/2013 Sb. NSS.

33 Rozsudek Nejvyššího správního soudu ze dne 10. 2. 2010, č. j. 2 Ans 5/2009-59.

34 Rozsudek Nejvyššího správního soudu ze dne 13. 8. 2009, č. j. 9 Ans 8/2009-149. Rozsudkem Nejvyššího správního soudu ze dne 11. 3. 2010, č. j. 5 Ans 2/2010-127 bylo stanoveno, že nečinnostní žalobou se nelze domáhat vydání usnesení podle odst. 6 \80 SpŘ. Takové usnesení navíc nenaplňuje znaky rozhodnutí dle ustanovení \65 SŘS a nepodléhá soudnímu přezkumu v rámci správního soudnictví.

35 SEDLÁČEK, S., 2011, op. cit., s. 57-58. 
Při věcném projednání žaloby soud rozhoduje na základě skutkového stavu zjištěného ke dni svého rozhodnutí (stejně jako v případě tzv. konstitutivního rozsudku o nezákonném zásahu). Je-li návrh žalobce důvodný, soud uloží rozsudkem nečinnému správnímu orgánu povinnost vydat (meritornî) ${ }^{36}$ rozhodnutí nebo osvědčení a stanoví k tomu přiměřenou lhůtu. Posouzení toho, zda je správní orgán nečinný, je otázkou důvodnosti žaloby a k hodnocení dochází až v samotném projednávání žaloby, nikoliv otázkou existence podmínek řízení. ${ }^{37}$ Volba prostředků nápravy nečinnosti přísluší správnímu soudu, nikoliv žalobci. ${ }^{38}$ Jedná se o postup totožný s postupem správního orgánu v rámci veřejné správy. Správní soud pouze uloží povinnost v dané věci rozhodnout (vydat osvědčení), nemůže stanovit obsah rozhodnutí (rozhodnout namísto správního orgánu). ${ }^{39}$ Úkolem nečinnostní žaloby je pouze odstranit nečinnost, nikoliv vydat rozhodnutí (osvědčenî) namísto prríslušného správního orgánu, kdy tímto postupem by správní soudy nepřípustně zasahovaly do kompetencí správních orgánů. Povinnost vydat rozhodnutí může soud uložit pouze věcně a místně príslušnému správnímu orgánu za podmínky, že takový správní orgán je rozhodnutí skutečně povinen vydat ${ }^{40}$ a současně byl určen v žalobním tvrzení, ${ }^{41}$ jelikož soud je vázán petitem žaloby (neplatí pro př́ípady ř́izení zahájené z moci úřední na základě podaného podnětu, kdy řízení nelze zahájit jinak než z úřední povinnosti $^{42}$ a v prrípadě nečinnosti se lze domáhat pouze vyřízení podnětu v zákonem stanovené lhůtě). Rízení o nečinnostní žalobě nelze zastavit z důvodu uspokojení žalobce (navrhovatele) po podání žaloby.

Soud je v průběhu rrízení o nečinnostní žalobě povinen zjistit, zda mezitím nebylo vydáno správní rozhodnutí, tedy zda nečinnost v době jeho rozhodování trvá, ${ }^{43}$ což představuje otázku důvodnosti žaloby, nikoliv podmínku př́pustnosti nečinnostní žaloby. Pokud by soud i po vydání správního rozhodnutí rozhodl o nečinnosti a uložil povinnost rozhodnutí (osvědčenî) vydat, Nejvyšší správní soud rozsudek zruší a věc vrátí (krajskému) soudu za účelem zamítnutí žaloby. ${ }^{44}$

36 Žalobce se žalobou nemůže domáhat vydání procesního rozhodnutí. K tomu srov. rozsudek Nejvyššího správního soudu ze dne 15. 12. 2004, č. j. 2 Ans 4/2004-116, publikovaný pod č. 506/2005 Sb. NSS.

37 Usnesení rozšířeného senátu Nejvyššího správního soudu ze dne 21. 9. 2010, č. j. 7 Ans 5/2008-164, publikované pod č. 2181/2011 Sb. NSS.

38 Rozsudek Nejvyššího správního soudu ze dne 18. 12. 2012, č. j. 9 Ans 16/2012-84.

39 JEMELKA, L. a kol., 2013, op. cit., s. 690.

40 Usnesení Nejvyššího správního soudu ze dne 8. 4. 2003, č. j. 5 A 170/2002-15, publikovaný pod č. $197 / 2004$ Sb. NSS.

41 Rozsudek Nejvyššího správního soudu ze dne 4. 11. 2004, č. j. 3 Ans 2/2004-60.

42 Rozsudek Nejvyššího správního soudu ze dne 30. 8. 2007, č. j. 4 Ans 6/2006-162.

43 Rozsudek Nejvyššího správního soudu ze dne 12. 6. 2006, č. j. 8 Ans 3/2005-107, publikovaný pod č. $931 / 2006$ Sb. NSS.

44 Rozsudek Nejvyššího správního soudu ze dne 15. 3. 2010, č. j. 8 Ans 1/2009-72, publikovaný pod č. 2258/2011 Sb. NSS. 
Nečinnostní žalobou se, jak již bylo řečeno, nelze domáhat nápravy nečinnosti správního orgánu v případech, kdy správní orgán již vydal rozhodnutí (osvědčenî); rovněž nelze požadovat určení, že správní orgán byl nečinný. „Nečinnost v takových př̌padech mữ̌e nabýt charakteru zásabu podle $\int 82$ a násl. SŘS a tzu. zásahovou žalobou se lze domáhat toliko určení nezákonnosti již ukončenébo zásabu...". ${ }^{45}$ Charakter nečinnosti coby nezákonných zásahů může nabýt nap̌r. při neudělení slova při jednání městského zastupitelstva, ${ }^{46}$ nezahájení přezkumného řízení, ${ }^{47}$ nezajištění řádného doručení již vydaného správního rozhodnutí, ${ }^{48}$ nezř́izení datové schránky na žádost osoby, které se datová schránka ze zákona nezři$z_{\text {zuje }}^{49}$ a v některých dalších případech. Zásahová žaloba ovšem nemá uplatnění pouze při ukončené nečinnosti nebo potřebě deklarace nečinnosti, nýbrž její úloha je mnohem výraznější. O tom dále v textu příspěvku.

Zásahová žaloba zaujímá v rámci základních žalobních typů (žaloba proti rozhodnutí, žaloba proti nečinnosti a zásahová žaloba) upravených soudním řádem správním postavení subsidiárního prostředku ochrany veřejných subjektivních práv ve správním soudnictví. Institut zásahové žaloby „...nemưže být vykládán jako jakási nábražka žaloby proti rozhodnuti správního orgánu... Prìtom plati, že žaloba proti rozhodnuti správního orgánu má pred žalobou proti nezákonnému zásahu prednost... Primo žalovat nezákonný zásah je proto možno jen tehdy, pakliže ochrana jinými právnimi prostredky neni možná. Vztab obou zminèných žalobnich typu take ląe označit za primát žaloby proti rozhodnutí, kdy sekundárni možnost podáni úspěsné žaloby proti nezákonnému zásabu nastupuje teprve tehdy, pokud žaloba proti roz̧odnutí nepripadá v úvahu... " ${ }^{50}$ Pokud jde o vztah zásahové a nečinnostní žaloby, opět má přednost nečinnostní žaloba před zásahovou. Zásahová žaloba tak stojí na samém okraji z pohledu žalobních typů upravených soudním řádem správním. Její důležitost nelze pomíjet, jelikož má nezastupitelné uplatnění ve správním soudnictví.

Zásahovou žalobou se žalobce může domáhat ochrany proti úkonům správních orgánů podřaditelných pod část IV. SpŘ s výjimkou osvědčení, proti faktickým úkonům s přímými právními důsledky (proti zásahům) a rovněž proti dalším formám činnosti veřejné správy.

Novelou soudního řádu správního s účinností od 1. 1. 2012 byla zavedena procesní obrana žalobce proti již ukončenému zásahu. Vedle konstitutivního rozhodnutí o nezákonném zásahu přibylo deklaratorní rozhodnutí soudu o nezákonnosti zásahu. „Nabizí se otázka, zda by již odeznèlá nečinnost nemobla splñovat pojmové znaky již odeznélého zásabu.

45 POTĚŠIL, L. a kol., 2014, op. cit., s. 754.

46 Rozsudek Nejvyššího správního soudu ze dne 5. 9. 2007, č. j. 3 Aps 7/2006-103.

47 Rozsudek Nejvyššího správního soudu ze dne 13. 1. 2016, č. j. 1 As 232/2015-44.

48 Rozsudek Nejvyššího správního soudu ze dne 25. 6. 2015, č. j. 2 As 190/2014-52.

49 Rozsudek Nejvyššího správního soudu ze dne 17. 10. 2013, č. j. 6 Ans 1/2013-66.

50 JEMELKA, L. a kol., 2013, op. cit., s. 659. K tomu srov. rozsudek Nejvyššího správního soudu ze dne 4. 8. 2005, č. j. 2 Aps 3/2004-42, publikovaný pod č. 720/2005 Sb. NSS. 
Ke kladné odpovédi totiž mų̛̌e vést závěr judikatury v tom smèru, že jiná nečinnost, než je uvedena

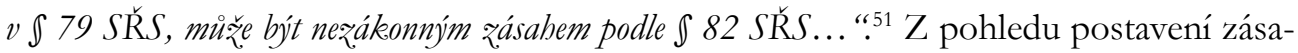
hové žaloby v rámci žalobních typů se její úloha jeví jako komplementární ve vztahu k nečinnostní žalobě. Zásahová žaloba tak poskytuje ochranu v př́padech, kdy se nelze proti nečinnosti bránit nečinnostní žalobou. Takové př́pady představuje skutečnost, kdy správní orgán již vydal rozhodnutí (osvědčenî), popř. správní orgán nevydal jiný správní akt/neučinil úkon, který není ani rozhodnutím, ani osvědčením, popř. je potřeba deklarovat nečinnost jako usnadnění postupu vedoucímu k náhradě škody způsobené nečinností jako nesprávným úředním postupem dle zákona č. 82/1998 Sb., o odpovědnosti za škodu způsobenou při výkonu veřejné moci rozhodnutím nebo nesprávným úředním postupem a o změně zákona České národní rady č. 358/1992 Sb., o notářích a jejich činnosti (notářský řád), ve znění pozdějších př̀edpisů (dále jen „OdpŠǩ"), kdy deklarování nečinnosti coby nezákonného zásahu žaloba proti nečinnosti neumožňuje. Nejdůležitější roli zásahové žaloby ve vztahu $\mathrm{k}$ nečinnosti zaujímá v př́padech domáhání se nápravy nečinnosti v př́padě neučinění úkonů jiných než nevydání meritorního rozhodnutí nebo osvědčení. Zásahová žaloba slouží jako náprava zákonné mezery.

Zásahová žaloba je nepřípustná, lze-li se ochrany nebo nápravy domáhat jinými právními prostředky; jedná se o již výše uvedenou subsidiaritu správního soudnictví (zásahové žaloby). Před podáním zásahové žaloby musí žalobce bezvýsledně vyčerpat prostředky nápravy poskytované veřejnou správou (výjimku pro deklaratorní výrok o nezákonném zásahu nyní ponechávám stranou pozornosti). Veřejná správa obecný prostředek nápravy neupravuje; výjimku představují některé prostředky nápravy obsažené ve zvláštních zákonech. V rámci samotné veřejné správy by jako prostředek nápravy mohla sloužit stížnost dle $\int 175$ SpŘ. Její vyčerpání ale není podmínkou př́pustnosti zásahové žaloby. ${ }^{52}$ Je tomu tak zejména proto, že stížnost dle $\int 175$ SpŘ představuje nenárokový prostředek ochrany subjektivních práv potenciálního žalobce. „Podminkou pro podáni návrbu (Žaloby) k soudu neni predchozi uplatnèni podnètu k provedeni prezkumnébo ř́zeni. Prezkumné rízeni müže být zahájeno jak pred zahájením rízeni soudního, tak naopak. "53 Prostředkem nápravy není ani ústavní stížnost, protože její podání podmiňuje marné vyčerpání prostředků ochrany ve veřejné správě a zároveň ve správním soudnictví, kterými jsou právě zásahová žaloba (a kasační stížnost). Z předchozího textu vyplývá, že zásahová žaloba tak (až na výjimky stanovené zvláštními zákony) poskytuje primární ochranu proti nezákonným zásahům. ${ }^{54}$

51 POTĚŠIL, L. a kol., 2014, op. cit., s. 776. K tomu srov. Rozsudek Nejvyššího správního soudu ze dne 29. 6. 2005, č. j. 6 Ans 1/2004-70.

52 Rozsudek Nejvyššího správního soudu ze dne 17. 12. 2010, č. j. 4 Aps 2/2010-44, publikovaný pod č. 2339/2011 Sb. NSS.

53 POTĚŠIL, L. a kol., 2015, s. 485.

54 PRŮCHA, P. Podstata a funkce správního soudnictví ve vztahu k ochraně veřejných subjektivních práv. In: SKULOVÁ, S. a kol. Prostredky ochrany subjektivních práv ve veřejné správé, 2014, op. cit. 
Nejvyšší správní soud ${ }^{55}$ se zabýval otázkou týkající se podmínek přípustnosti zásahové žaloby. Stanovil 6 podmínek, které musí být splněny kumulativně, aby se soud mohl zásahovou žalobou meritorně zabývat.

a) Zásahem správního orgánu došlo ke zkrácení práv subjektu (žalobce).

b) Zkrácení práv musí postihnout samotného žalobce.

c) Zásah správního orgánu musí být nezákonný.

d) Ze strany správního orgánu se jednalo o zásah ve smyslu legislativní zkratky obsažené v $\int 82$ SŘS, tedy o nezákonný zásah, pokyn nebo donucení.

e) Zásah správního orgánu byl zaměřen prímo proti žalobci nebo v důsledku zásahu správního orgánu bylo proti žalobci př́mo zasaženo.

f) Důsledky nezákonného zásahu správního orgánu musí trvat nebo musí hrozit jeho opakování. Tato podmínka byla s účinností od 1. 1. 2012 zrušena.

Skutkovým a právním stavem v prrípadě konstitutivního výroku o nezákonném zásahu je stav, jaký existoval ke dni rozhodnutí (stejně jako v případě rozhodování o nečinnostní žalobě). Pokud se žalobce domáhá pouze deklaratorního výroku o nezákonném zásahu (o tom, že již skončená nečinnost byla nezákonná), správní soud vychází ze skutkového a právního stavu, který existoval v době zásahu; soud rozsudkem určí, že již ukončená nečinnost byla nezákonná. Trvá-li nezákonný zásah (nečinnost) v době rozhodování nebo trvají-li jeho důsledky anebo hrozí-li jeho opakování, soud zakáže správnímu orgánu, aby pokračoval $\mathrm{v}$ porušování žalobcových subjektivních práv, a přikáže, je-li to možné, aby obnovil stav před zásahem (nečinnostî).

\section{Nečinnost a nezákonný zásah: rozdílné kategorie či nikoliv?}

Nejprve se zaměřím na právní úpravu nečinnosti obsaženou ve správním řádu. Nečinnost dle správního řádu představuje jakékoliv nekonání v př́padě, kdy zákon povinnost činit nějaký úkon ukládá. Nezákonný zásah ve veřejné správě bývá vymezován jako úkon správního orgánu, který není správním rozhodnutím, směřuje vůči adresátům, pro které je závazný a ty jsou povinny na jeho základě něco konat, nějaké činnosti se zdržet nebo nějaké jednání strpět. Společně pro nečinnost i nezákonný zásah platí, že platná právní úprava neobsahuje jejich legální definice. $V$ rámci ochrany proti nečinnosti správní ráa obsahuje 4 prostředky ochrany proti nečinnosti. Opatřeními proti nečinnosti dle ustanovení $\int 80 \mathrm{SpR}$ se lze domáhat ochrany proti nečinnosti v podobě nevydání meritorního rozhodnutí včetně nečinnosti u jakýchkoliv postupů a úkonů správních orgánů upravených správním řádem, nebo úkonů, na které se správní řád vztahuje. Je to dáno díky odkazu v ustanovení $\int 6$ odst. 1 SpŘ.

55 Rozsudek Nejvyššího správního soudu ze dne 17. 3. 2005, č. j. 2 Aps 1/2005-65, publikovaný pod č. $603 / 2005 \mathrm{Sb}$. NSS. 
Obecný prostředek ochrany proti nezákonným zásahům není ve správním řádu upraven. Nápravu nezákonných zásahů poskytují pouze prostředky upravené ve zvláštních zákonech. Podle mého názoru absence obecného prostředku nápravy nezákonných zásahů ve správním řádu představuje deficit, kterým veřejná správa přesunuje svoji pravomoc rozhodnout o takovém prostředku nápravy do správního soudnictví. Přitom, jak již bylo zmíněno, správní soudnictví je založeno na zásadě subsidiarity. Subsidiarita správního soudnictví přitom „,... dává prostor k tomu, aby prípadná nezákonnost mobla být nejprve odstranèna vlastnimi mechanismy veřejné správy a až v prĭpadèjejich selháni ve správním soudnictvi". "Zároveň platí, že „...úkolem správního soudnictví neni suplovat rízeni pred správním orgánem ... " ${ }^{\text {"57, }}$ tedy nápravu závadného stavu by prvotně měla napravit veřejná správa a až v případě, že by dle názoru žalobce nebyla veřejným subjektivním právům poskytnuta řádná (dostatečná) ochrana, tak teprve potom se nápravy domáhat ve správním soudnictví. Jeví se jako zcela předčasné domáhat se nápravy nezákonných zásahů ve veřejné správě (až na výjimky dané opravnými prostředky ve zvláštních zákonech) ihned ve správním soudnictví bez zapojení samotné veřejné správy. Zastávám názor, že současná právní úprava obsažená ve správním řádu je částečně v rozporu s uvedenou zásadou subsidiarity. Považoval bych za zcela správné vytvoření univerzálního prostředku nápravy ve veřejné správě proti nezákonným zásahům, jež by měl subsidiární povahu ve vztahu ke zvláštním zákonům.

Žaloba proti nečinnosti připouští ochranu u dvou případů nečinnosti, a to u nevydání meritorního rozhodnutí (mající povahu rozhodnutí dle ustanovení $\int 65$ SŘS) a v případě nevydání osvědčení. Zásahovou žalobou se lze bránit proti úkonům systematicky zařazeným do části IV. SpŘ (z nichž osvědčení má zvláštní postavení), proti faktickým úkonům s přímými právními důsledky a proti některým dalším formám činnosti veřejné správy. Pokud jde o vztah nečinnostní a zásahové žaloby, zásahová žaloba má subsidiární povahu vůči nečinnostní žalobě. ${ }^{58}$ Zásahová a nečinnostní žaloba jsou dva odlišné druhy žalob (žalobní typy), které nelze zaměňovat. ${ }^{59}$

Ochrana proti nečinnosti ve veřejné správě a ve správním soudnictví spolu plně nekorespondují (stejně je tomu i v př́padě nezákonného zásahu). V rámci veřejné správy se lze domáhat opatřeními proti nečinnosti nápravy nečinnosti u jakékoliv formy realizace veřejné správy, zatímco ve správním soudnictví se lze domáhat ochrany pouze proti nevydání rozhodnutí ve věci samé nebo osvědčení. Ochranu proti nezákonnému zásahu poskytuje veřejná správa spíše sporadicky ( $\mathrm{k}$ tomu srov. předchozí text), zatímco správní

56 Rozsudek Nejvyššího správního soudu ze dne 7. 11. 2013, č. j. 9 Aps 4/2013-25, publikovaný pod č. 2956/2014 Sb. NSS.

57 Rozsudek Nejvyššího správního soudu ze dne 25. 5. 2017, č. j. 9 As 34/2016-53.

58 Rozsudek Nejvyššího správního soudu ze dne 27. 7. 2017, č. j. 3 As 166/2016-36.

59 JEMELKA, L. a kol., 2013, op. cit., s. 683. K tomu srov. rozsudek Nejvyššího správního soudu ze dne 9. 7.2009 , č. j. 7 Aps 2/2009-197. 
soudnictví poskytuje ochranu proti nezákonným zásahům, které nejsou rozhodnutím, a zároveň se ochrany nelze domáhat žalobou proti nečinnosti (a žalobou proti rozhodnutí správního orgánu). Nezákonným zásahem ve správním soudnictví může být i nečinnost, zatímco ve veřejné správě by ochranu plně poskytovalo některé z opatření proti nečinnosti. Skutečnost, že nezákonná nečinnost správního orgánu spočívající v jiném nekonání než nevydání rozhodnutí ve věci samé nebo osvědčení, může nabýt charakteru nezákonného zásahu (nezákonným zásahem nemusí být pouze aktivní konání správních orgánů, ale i pasivita) poprvé uvedl Ústavní soud, ${ }^{60}$ později i rozššřený senát Nejvyššího správního soudu ze dne 16. 11. 2010, č. j. 7 Aps 3/2008-98. Od této chvíle nabyl nezákonný zásah v rámci správního soudnictví „nové kvality“, kdy „ochudil“ nečinnostní žalobu o část případů jejího potenciálního soudního přezkumu v rámci tohoto žalobního typu za podmínky, kdy by šíre záběru nečinnostní žaloby sledovala šíri záběru opatření proti nečinnosti ve veřejné správě. Uvedené tvrzení chce vnímat s nadsázkou, jelikož zásahová žaloba připravila nečinnostní žalobu o část předmětu jejího přezkumu z důvodu omezení rozsahu přezkumu nečinnosti na meritorní rozhodnutí a osvědčení.

Případy nečinnosti, které jsou napadnutelné nečinnostní žalobou, jsou oproti veřejné správě podstatně omezeny. Nečinnostní žaloba poskytuje užší rámec ochrany proti nečinnosti než samotná veřejná správa $v$ rámci opatření proti nečinnosti. Podle mého názoru jsou podmínky přípustnosti nečinnostní žaloby v soudním řádu správním stanoveny v nepřiměřeně úzkém rozsahu. Již ze samotného jazykového výkladu pojmu nečinnost vyplývá, že de lege ferenda by žaloba proti nečinnosti měla poskytovat ochranu proti ,jakékoliv“ nečinnosti ve veřejné správě. Domnívám se, že by takový počin jednoznačně zpřehlednil žalobní typy, zejména pokud jde o odlišení nečinnostní a zásahové žaloby. Opačný směr, který nelze rozporovat a ke kterému se přikláním, představuje možnost považovat jakoukoliv formu nečinnosti za nezákonný zásah, jelikož nečinnost znaky nezákonného zásahu, jež byly uvedeny v textu výše, nepochybně naplňuje. Nečinnost je svým způsobem druhem zásahu, vyznačující se pasivním jednáním orgánů veřejné správy. Pojem nečinnosti je užším než pojem zásah. Do roku 2010 se nezákonné zásahy vyznačovaly znakem aktivního konání ze strany správních orgánů a nečinnost jako pasivita (nekonánî) ze strany správních orgánů. Uvedené smysluplné dělení by existovalo i nadále, dokud se nevyskytl problém, jaký žalobní typ by měl poskytovat ochranu veřejných subjektivních práv žalobce $\mathrm{v}$ př́padech, kdy žaloba proti nečinnosti nebyla př́pustná. Vzhledem k subsidiaritě zásahové žaloby tak ochrana práv žalobce připadla právě tomuto žalobnímu typu.

Shrnujíc posledně uvedené, uvádím, že vyslovené názory „dělí“ odbornou veřejnost na 2 názorové linie, a to kvůli názoru, jak by bylo možné problematiku nekoncepčnosti ochrany proti nečinnosti ve veřejné správě a ochrany poskytované nečinnostní žalobou řešit ( $\mathrm{ad}$ a) a ad c) níže). Podle mého názoru existují 3 možnosti řešení, a to: a) ponechat 
právní úpravu v současném znění a pokračovat v dosavadním dualismu soudní ochrany nečinnosti, b) novelizovat soudní řád správní tak, aby ustanovení $\int 79$ odst. 1 SŘS bylo ve znění např. Ten, kdo bezvýsledně vyčerpal prostředky, které procesní předpis platný pro rrízení u správního orgánu stanoví k jeho ochraně proti nečinnosti správního orgánu, může se žalobou domáhat, aby soud uložil správnímu orgánu povinnost vydat rozhodnutí ve věci samé nebo učinit jiný úkon, k němuž je ze zákona povinen. Další možností znění uvedeného ustanovení soudního řádu správního je inspirace slovenskou právní úpravou správního soudnictví (konkrétně ustanovení \ 242 odst. 1 zákona č. 162/2015 Z. z., správny súdny poriadok), který zní: „Žalobca sa môže žalobou domáhat’ odstránenia nečinnosti orgánu verejnej správy $v$ začatom administrativnom konani." Kombinací ustanovení českého a slovenského procesního předpisu upravujícího správní soudnictví by mohl vzniknout odstavec 1 ve znění: Ten, kdo bezvýsledně vyčerpal prostředky, které procesní předpis platný pro řízení u správního orgánu stanoví k jeho ochraně proti nečinnosti správního orgánu, může se žalobou domáhat odstranění nečinnosti správního orgánu v zahájeném správním řízení nebo $\mathrm{v}$ př́padě neprovedení úkonu, k němuž je správní orgán ze zákona povinen. Nyní jsem chtěl pouze demonstrovat možnosti znění \ 79 odst. 1 SŘS, jež by si zasloužilo ještě více péče tak, aby bylo pamatováno na veškeré prrípady nečinnosti ve veřejné správě. Možnost ad c) představuje spojení žalobních typů nečinnostní a zásahové žaloby s tím, že by se nadále jakákoliv nečinnost považovala za nezákonný zásah (podrobnosti byly uvedeny výše). Výhodami a úskalími spojení těchto žalobních typů se budu zabývat závěrem kapitoly.

Pokud z podání není patrné, zda se žalobce domáhá ochrany proti nečinnosti nebo ochrany proti nezákonnému zásahu, musí jej správní soud vyzvat, aby specifikoval žalobní typ. ${ }^{61}$ Pokud žalobce v soudem určené lhůtě podání neopraví a takový nedostatek brání pokračování v řízení, soud žalobu usnesením odmítne. Ve správním soudnictví se podle stávající judikatury nepřipouští alternativní či eventuální petit v př́ípadech, kdy ona alternativa (eventualita) by měla spočívat v odlišných žalobních typech. ${ }^{62}$ „To je odน̊vodnèno zejména faktem, že jednotlivým žalobnim typuim odpovidají v soudním rádu správním relativnè samostatné procesni úpravy, keteré se liši co do stanoveni počatku běbu lhùt ke uplatnèni zaaloby, jejich náležitostí, úpravy aktivni i pasivni procesni legitimace, úpravy toho, k.jakému datu soud zjïš̀tuje skutkový a právni stav atd. Bylo by proto mimorádně obtižné vést rízeni o jedné a též žalobě tak, aby bylo možno na jeho konci rozhodnout v souladu s požadavky kterékoliv z.procesnich úprav pripadajicich bypoteticky v úvahu. Žalobci, který si neni jist, jaký typ žaloby by mél využit ko ochraně svých práv... a chce zprocesni opatrnosti vyčrpat vice možností, tak nezbývá nežpodat několik samostatných žalob proti témuž konáni č opomenuti ze strany státni správy, byt tak mǐ̌e fakticky učinit v jediném podání. Za každou takto podanou žalobu také musi zaplatit samostatně soudni poplatek... Jinou situaci

61 Rozsudek Nejvyššího správního soudu ze dne 3. 5. 2018, č. j. 8 As 279/2017-78 a mnohé další.

62 Rozsudek Nejvyššího správního soudu ze dne 4. 5. 2017, č. j. 9 As 329/2016-42. 


\section{je prǐpad neurčité či nejednoznačné žaloby, kdy mưže žalobce na výzun soudu petit upresnit jedním} č drubým smèrem. "63

Problematika nejednoznačnosti správného žalobního typu se rovněž vyskytuje u rozhodování, zda využít žalobu proti rozhodnutí správního orgánu nebo naopak žalobu zásahovou. Rozhraničení 3 základních žalobních typů není zcela jednoznačné a činí potíže nejen u laické veřejnosti, jak je i ze samotné judikatury patrné, ale i v řadách právníků. Nemusím podotýkat, že takový stav je zcela nežádoucí. Otázka do budoucnosti však zní, zda je možné nejednoznačnosti žalobních typů předejít. Objevují se různá možná řešení. Začnu od toho nejkontroverznějšího, kdy zazněla myšlenka, zda 3 základní žalobní typy nespojit v jednu „univerzální“ žalobu. Uvedený názor je zcela menšinový a rovněž já jej nepovažuji za správný. Zákonodárce při vytváření soudního řádu správního dbal na to, aby správní soudnictví poskytovalo ochranu subjektivních práv zasažených rozhodnutím, nečinností nebo zásahem jednotlivými žalobními typy. Cílem bylo předejít stavu, který panoval do přjietí procesního předpisu upravujícího správní soudnictví, kdy ochrana byla poskytována pouze proti správním rozhodnutí. Zákonodárce tak sledoval prrehlednost žalobních typů s cílem vzbudit přesvědčení, že proti každému úkonu ze strany správních orgánů je přípustná ochrana ve správním soudnictví. Ačkoliv by se vznikem „univerzální žaloby“ nedošlo k navrácení do situace panující do konce roku 2002, (nejen) pro laickou veřejnost by se správní soudnictví stalo nepřehledným. Navíc by taková žaloba činila interpretační obtíže; bud' by byla prrípustná proti jakémukoliv úkonu správního orgánu za jakýchkoliv okolností, nebo by bylo nutné stanovovat podmínky prípustnosti žaloby, které ale nelze stanovit všeobecné pro celé správní soudnictví. Správní soudnictví by se tak dostalo do situace, kdy i uvedená žaloba by musela být dále specifikována pro dílčí typizované případy soudního přezkumu, čímž by se nápadně přiblížila současné právní úpravě v soudním řádu správním. Z těchto důvodů takový názor považuji za nerealizovatelný. Další názor spočívá v tom, zda nespojit žalobu proti rozhodnutí a zásahovou žalobu. Ani s tímto názorem se neztotožňuji. Důvodem mého nesouhlasu je skutečnost, že pro právní praxi by bylo zjevně př́nosnějším jednoznačné vymezení pojmu rozhodnutí a zásah, k čemuž ani po více než 15 letech po nabytí účinnosti soudního řádu správního a zrŕżení Nejvyššího správního soudu nedošlo a výklad uvedených pojmů se dosud dostatečně neustálil. Další podrobnosti vzhledem k tématu prríspěvku ponechám stranou. Poslední variantu, a to pro nynější př́spěvek stěžejní, představuje možnost spojení nečinnostní a zásahové žaloby. Tomuto tématu se věnuji ve zbytku této kapitoly.

Již výše bylo uvedeno, že nečinnostní žaloba je přípustná pouze proti nevydání meritorního rozhodnutí a osvědčení, nikoliv proti nevydání rozhodnutí procesního. L. Potěšil ${ }^{64} \mathrm{k}$ tomu uvádí, že „žaloba (proti nečinnosti, pozn. autora) nemá povahu univerzálního

63 Rozsudek Nejvyššího správního soudu ze dne 4. 5. 2017, č. j. 9 As 329/2016-42.

64 POTĚŠIL, L. a kol., 2014, op. cit., s. 754. 
prostredku ochrany proti nečinnosti správního orgánu... ". S takovým tvrzením nelze nic jiného než bezvýhradně souhlasit. Osvědčení zaujímá specifické postavení, kdy se jedná o jiný (pojmenovaný) úkon podle části IV. SpŘ. Ochranu v př́ípadě jeho nevydání poskytuje nečinnostní žaloba. Proti nezákonnému vyjádření a sdělení jako zbylým pojmenovaným úkonům dle části IV. SpŘ ochranu naopak poskytuje zásahová žaloba. Stejný závěr platí i pro tzv. nepojmenované úkony podle části IV. Spř. Pokud by ochranu proti jejich neprovedení neposkytovala ani zásahová žaloba jako subsidiární žalobní typ (tedy v př́ípadech, kdy ochranu subjektivních práv nemůže poskytnout žaloba proti rozhodnutí ani žaloba proti nečinnosti), jednalo by se o nepřípustný zásah do ústavně garantovaného práva na soudní ochranu před jednáním orgánu veřejné správy dle článku 36 usnesení předsednictva České národní rady o vyhlášení Listiny základních práv a svobod jako součástí ústavního pořádku České republiky (dále jen „Listina základních práv a svobod“). Není rozhodné, který žalobní typ ochranu veřejných subjektivních práv poskytuje, důležité je, že taková ochrana poskytována je. Osobně považuji za naprosto zbytečně složité dělení jiných úkonů podle žalobního typu (což bezprostředně souvisí se shora uvedenými návrhy de lege ferenda).

Jsem plně přesvědčen, že za současného znění soudního řádu správního by k ochraně proti nečinnosti ve veřejné správě plně postačovala zásahová žaloba. Již jsem zmínil, že nečinnost lze považovat za užší pojem než zásah. Nezákonná nečinnost naplňuje znaky nezákonného zásahu, nebot’ oběma úkony je zasahováno př́mo do veřejných subjektivních práv potenciálního žalobce. Zásah může dle judikatury spočívat i v pasivitě jednání správního orgánu, tedy v nekonání (nečinnosti). Bylo by nanejvýš vhodné sloučení nečinnostní a zásahové žaloby v jeden žalobní typ - zásahovou žalobu zahrnující i ochranu proti nečinnosti, a považovat jakoukoli formu nečinnosti za nezákonný zásah správního orgánu. Stejný názor zastává i K. Frumarováa ${ }^{65}$ kdy v příspěvku pokládá řečnickou otázku, zda nepojímat jakoukoli formu nečinnosti správního orgánu jako nezákonný zásah. S jejím názorem se plně ztotožňuji.

„Nová“ právní úprava zásahové žaloby by doznala pouze dílčích změn. V rámci žalobní legitimace by ustanovení bylo doplněno tak, že by znělo: Každý, kdo tvrdí, že byl přímo zkrácen na svých právech nezákonným zásahem, pokynem, donucením nebo nečinností (dále jen ,zásah“) správního orgánu... Změna by ale nebyla bezpodmínečně nutná; judikatorně by se dovodilo, že zásahem je i jakákoliv forma nečinnosti. Změny by doznalo i označení dílu 3 hlavy druhé části třetí SŘS, který by nesl název řízení o ochraně před nezákonným zásahem, pokynem, donucením nebo nečinností správního orgánu. Podmínky př́pustnosti by se nijak neměnily, stále by platila povinnost vyčerpat „opravné“ prostředky poskytované veřejnou správou, jako je tomu $\mathrm{v}$ ustanovení $\int 85 \mathrm{SŘS}$.

65 FRUMAROVÁ, K. Žaloba na ochranu před nezákonným zásahem správního orgánu (vybrané aspekty). In: SLÁDEČEK, V. a P. MELOTÍKOVÁ. Aktuální otázky správníbo soudnictví (zejména v souvislosti s novelou soudníbo rádu správníbo provedenou zákeonem č. 303/2011 Sb.). Praha: Leges, 2012, s. 38. 
Pasivní žalobní legitimace by zůstala beze změny. Změny by ale doznala lhưta pro podání žaloby. Ustanovení $\int 84$ odst. 1 SŘS by zůstalo beze změn, za něj by se vložil odstavec 2 (a ostatní odstavce by se přečíslovaly), který by vycházel z ustanovení $\int 80$ odst. 1 SŘS, a zněl by: Jestliže se žalobce domáhá ochrany proti nevydání rozhodnutí ve věci samé, žalobu lze podat nejpozději do jednoho roku ode dne, kdy ve věci, v níž se žalobce domáhá ochrany, marně proběhla lhůta stanovená zvláštním zákonem pro vydání rozhodnutí, a není-li taková lhůta stanovena, ode dne, kdy byl žalobcem vưči správnímu orgánu nebo správním orgánem proti žalobci učiněn poslední úkon. Tím bych zachoval dosavadní štěpení lhůt v př́padě nečinnosti u nevydání rozhodnutí a u nečinnosti v rámci ostatních úkonů. Nově by se ochrany proti nevydání osvědčení bylo možné domáhat ve stejné lhůtě jako proti jiným úkonům dle části IV. SpŘ. Pokud jde o petit zásahové žaloby, do odstavce 2 ustanovení $\int 87$ SŘS by za 1. Větu byla vložena 2. věta ve znění: Je-li návrh důvodný, soud uloží rozsudkem správnímu orgánu povinnost vydat rozhodnutí a stanoví k tomu přiměřenou lhůtu, ne však delší, než kterou určuje zvláštní zákon. Téměř identické znění ustanovení \ 81 odst. 2 SŘS by se přeneslo do úpravy zásahové žaloby. Z výše uvedeného je nanejvýš patrné, že změny by byly pouze dílčí, což dokazuje blízkost právní úpravy nečinnostní a zásahové žaloby.

Výhodu spojení žaloby proti nečinnosti a zásahové žaloby lze spatřovat v odstranění nejednoznačnosti použití správného žalobního typu. Již jsem zmínil, jaké důsledky současná rozkolísaná právní úprava přináší. Žalobce si často neví rady, který žalobní typ uplatnit a tak raději volí cestu dvou žalob a dvou soudních poplatků, což lze vnímat jako „překážku př́stupu k soudu“, kdy aby byl žalobce úspěšný tak raději zaplatí 2 poplatky, než aby jeho subjektivní právo nebylo chráněno důsledkem nesprávného žalobního typu. Další výhodu představuje částečné zrychlení soudního procesu, nebot' při podání žaloby s eventuálním (alternativním) petitem musí soud vyzvat žalobce $\mathrm{k}$ upřesnění petitu, tedy aby zvolil, zda se domáhá ochrany proti nečinnosti nebo ochrany proti nezákonnému zásahu. Současné znění správního řádu vyžaduje dobrou orientaci $\mathrm{v}$ textu zákona, tedy pro laickou veřejnost, které je předpis rovněž určen, se stává nesrozumitelným. Zaměřím-li se na úskalí spojení žalobních typů, teoretickou nevýhodou je snížení počtu žalobních typů. Praktickým problémem může být skutečnost, že ochrana proti nečinnosti ve správním soudnictví nebude mít výslovné zastoupení žalobním typem. Výhody spojení žalobních typů dle mého názoru předčívají prrípadná úskalí, proto zastávám názor o opodstatněnosti spojení.

\section{Závěr}

Předmětem tohoto článku je ochrana proti nečinnosti a nezákonným zásahům ve veřejné správě. Samotná veřejná správa zná z hlediska správního řádu ochranu proti nečinnosti, nikoliv proti nezákonnému zásahu. Judikatorně bylo potvrzeno, že stížnost dle $\int 175 \mathrm{SpR}$ ani přezkumné řízení není dostatečným prostředkem ochrany veřejných subjektivních 
práv proti nezákonným zásahům ve veřejné správě. Často bývá prvotním prostředkem ochrany takových práv tzv. zásahová žaloba díky absenci prostředků nápravy nezákonného zásahu v rámci veřejné správy. Tuto absenci považuji, jak jsem již uvedl, za částečně kolidující s ustanovením $\int 5$ SŘS a dle mého názoru by veřejná správa měla mít možnost př́padný nezákonný zásah odstranit svými mechanismy a až v př́padě jejich „selhání“ se nápravy domáhat ve správním soudnictví. V prŕípadě nečinnostní žaloby je situace opačná, tedy žalobce musí vyčerpat žádost o uplatnění opatření proti nečinnosti před samotným podáním žaloby.

Zásahová a nečinnostní žaloba mají mnoho společných znaků. V př́padě soudního přezkumu nečinnosti se setkáváme s tzv. dvojkolejností, kdy ochranu práv žalobce poskytuje nečinnostní žaloba a zásahová žaloba jako komplementární žalobní typ. V praxi se mimo jiných řešení dvoukolejnosti ochrany subjektivních práv proti nečinnosti vyskytují názory podporující myšlenku sjednocení obou žalobních typů. Takový názor rovněž zastávám. Jakákoliv nečinnost by měla být považována za nezákonný zásah, čímž by se odstranily praktické problémy s rozlišováním uvedených žalobních typů. $\mathrm{V}$ příspěvku jsem se zaměřil na podstatné rysy žaloby proti nečinnosti a zásahové žaloby s možností jejich spojení. Rovněž jsem provedl zhodnocení přínosu a na druhé straně úskalí takového spojení a uvedl jsem, jak by mohl „nový typ“ žaloby vypadat. Výhody spojení obou žalobních typů převažují nad úskalími. Z provedené komparace je zcela patrné, že změny v důsledku spojení žalobních typů by byly pouze dílčí bez zásadnějšího vlivu na soudní přezkum nečinnosti ve veřejné správě. Žalobcům by nepochybně bylo posíleno legitimní očekávání, že v případě podání „nové“ zásahové žaloby bude taková žaloba za splnění podmínky př́pustnosti věcně projednána. Dosud panuje nejistota, který žalobní typ užít. Nejistota nepanuje pouze mezi laickou veřejností, ale nade vši pochybnost i v právní praxi, což celý problém podtrhuje.

Ochranu proti nečinnosti nadále poskytují 2 žalobní typy, tedy zásahová a nečinnostní žaloba. Zdali bude uvedená dvojkolejnost přetrvávat i nadále, ukáže čas. V dohledné době se změna soudního řádu správního zahrnující sloučení žalobních typů neplánuje. I když se judikatura s vcelku složitou právní úpravou vypořádala, nanejvýš vhodné by bylo promítnutí racionálnějšího řešení do právní úpravy v soudním řádu správním. 